Pacific Journal of Mathematics

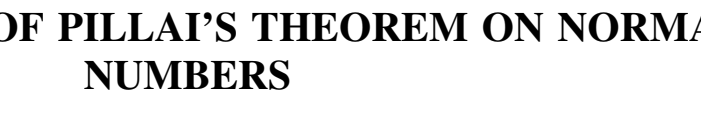




\title{
A SHORT PROOF OF PILLAI'S THEOREM ON NORMAL NUMBERS
}

\author{
JOHN E. MAXFIELD
}

1. Introduction. The object of this paper is to give a short proof of the Pillai theorem [2] on nornal numbers using the Niven-Zuckerman result [1] as a tool.

DEFinition 1. A number $\sigma$ is simply normal to the base $r$ if, in the expansion to the base $r$ of the fractional part of $\sigma$, we have $\lim _{n \rightarrow \infty} n_{c} / n=1 / r$ for all $c$, where $n_{c}$ is the number of occurrences of the digit $c$ in the first $n$ digits of $\sigma$.

DEFinition 2. A number $\sigma$ is normal to the base $r$ if $\sigma, r \sigma, r^{2} \sigma, \ldots$ are each simply normal to all the bases $r, r^{2}, r^{3}, \ldots$.

ThEOREM (Pillai). A necessary and sufficient condition that a number $\sigma$ be normal to the base $r$ is that it be simply normal to the bases $r, r^{2}, r^{3}, \ldots$

2. Proof. The necessity of the condition follows from the definition of normality.

To prove sufficiency, assume that $\sigma$ is simply normal to the bases $r, r^{2}, \ldots$. Let $A=\left(a_{1} a_{2} \cdots a_{v}\right)$ be any fixed sequence of digits (to base $r$ ), where $v=h r-s, h>0,0 \leq s<r$; and consider the occurrence of $A$ in $\sigma$. Count the number of occurrences of $A$ in the collection of sequences of length $h r$. There are $s$ digits free after $v$ of the $h r$ digits are fixed. Thus there are $(s+1) r^{s}$ different occurrences of $A$ in these sequences.

For any positive integer $n$, define $f_{n}(A)$ to be the frequency of the occurrences of $A$ in $\sigma$ except in places where $A$ will straddle the middle of sequences of length $2 h 2^{n-1} r$ starting in places congruent to $1\left(\bmod 2 h 2^{n-1} r\right)$, or where $A$ will straddle the middle of sequences of length $4 h 2^{n-1} r$ starting in places congruent to $1\left(\bmod 4 h 2^{n-1} r\right)$, or $\cdots$, or where $A$ will straddle the middle of sequences of length $2^{s} h 2^{n-1} r$ starting in places congruent to $1\left(\bmod 2^{s} h 2^{n-1} r\right)$, and so on.

Certainly $\lim _{n \rightarrow \infty} f_{n}(A)$, if it exists, will be equal to $f(A)$, the frequency of $A$ in $\sigma$.

We have

$$
f_{1}(A)=\frac{(s+1) r^{s}}{h r r^{h r}}=\frac{1}{r^{v}}-\frac{v-1}{h r^{v+1}},
$$


since there are $h r$ digits of $\sigma$ to base $r$ in each digit of $\sigma$ to base $r^{h r}$, and $\sigma$ is simply normal to the base $r^{h r}$. The number of occurrences of $A$ straddling the middle of blocks of length $2 h r$ is $(v-1) r^{2 h r+s}$. The frequency of these in $\sigma$, where the sequence of length $2 h r$ starts in a place congruent to $1(\bmod 2 h r)$, is

$$
\frac{(v-1) r^{2 h r+s}}{2 h r r^{2 h r}}=\frac{v-1}{2 h r^{v+1}},
$$

since there are $2 h r$ digits of $\sigma$ to base $r$ to each digit of $\sigma$ to base $r^{2 h r}$.

Thus

$$
f_{2}(A)=\frac{1}{r^{v}}-\frac{v-1}{h r^{v+1}}+\frac{v-1}{2 h r^{v+1}} .
$$

Similarly,

$$
f_{3}(A)=f_{2}(A)+\frac{v-1}{4 h r^{v+1}}=\frac{1}{r^{v}}-\frac{v-1}{h r^{v+1}}+\frac{v-1}{h r^{v+1}}\left[\frac{1}{2}+\frac{1}{4}\right]
$$

and

$$
f_{n}(A)=\frac{1}{r^{v}}-\frac{v-1}{h r^{v+1}}+\frac{v-1}{h r^{v+1}} \sum_{i=1}^{n-1} 1 / 2^{i} .
$$

It follows that

$$
\lim _{n \rightarrow \infty} f_{n}(A)=1 / r^{v}
$$

Accordingly, by the Niven-Zuckerman result [1], stating that a necessary and sufficient condition in order that a number $\sigma$ be normal is that every fixed sequence of $v$ digits occur in the expansion of $\sigma$ with the frequency $1 / r^{v}$, we see that $\sigma$ is normal to the scale $r$.

\section{REFERENCES}

1. Ivan Niven and H. S. Zuckerman, On the definition of normal numbers. Pacific J. Math. 1 (1951), 103 - 109.

2. S. S. Pillai, On normal numbers, Proceedings of the Indian Acad. Sci., Section A, 12 (1940), 179-184. 


\section{EDITORS}

HERBERT BUSEMANN

University of Southern California

Los Angeles 7, California
R. M. ROBINSON

University of California

Berkeley 4, California

E. F. BECKENBACH, Managing Editor

University of California

Los Angeles 24, California

\section{ASSOCIATE EDITORS}

\author{
R. P. DILWORTH \\ HERBERT FEDERER \\ MARSHALL HALL
}

P. R. HALMOS

HEINZ HOPF

R. D. JAMES

\author{
BØRGE JESSEN \\ PAUL LÉVY \\ GEORGE PÓLYA
}

J. J. STOKER
E. G. STRAUS

KÖSAKU YOSIDA

\section{SPONSORS}

UNIVERSITY OF BRITISH COLUMBIA

CALIFORNLA INSTITUTE OF TECHNOLOGY

UNIVERSITY OF CALIFORNIA, BERKELLEY

UNIVERSITY OF CALIFORNIA, DAVIS

UNIVERSITY OF CALIFORNIA, LOS ANGELES

UNIVERSTTY OF CALIFORNIA, SANTA BARBARA

OREGON STATE COLLEGE

UNIVERSITY OF OREGON
UNIVERSETY OF SOUTHERN CALIFORNIA STANFORD UNIVERSITY

WASHINGTON STATE COLLEGE UNIVERSTTY OF WASHINGTON

AMERICAN MATHEMATICAL SOCIETY NATIONAL BUREAU OF STANDARDS, INSTITUTE FOR NUMERICAL ANALYSIS

Vari-Type Composition by

Elaine Barth

Delores Gilbertson

With the cooperation of

E. F. Beckenbach

E. G. Straus

Printed in the United States of America by

Edwards Brothers, Inc., Ann Arbor, Michigan

UNIVERSITY OF CALIFORNIA PRESS * BERKELEY AND LOS ANGELES

COPYRIGHT 1952 BY PACIFIC JOURNAL OF MATHEMATICS 


\section{Pacific Journal of Mathematics}

\section{Vol. 2, No. $1 \quad$ January, 1952}

Tom M. (Mike) Apostol, Theorems on generalized Dedekind sums ........ 1

Tom M. (Mike) Apostol, Addendum to 'On the Lerch zeta function' ........ 10

Richard Arens, Extension of functions on fully normal spaces ........... 11

John E. Maxfield, A short proof of Pillai's theorem on normal numbers.... 23

Charles B. Morrey, Quasi-convexity and the lower semicontinuity of multiple integrals................................ 25

P. M. Pu, Some inequalities in certain nonorientable Riemannian manifolds....................................... 55

Paul V. Reichelderfer, On the barycentric homomorphism in a singular

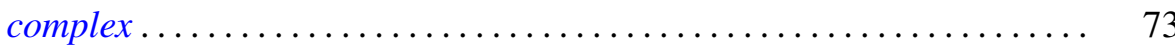

A. H. Stone, Incidence relations in multicoherent spaces. III ........... 99 